\title{
A CSŐDELŐREJELZÉS FEJLŐDÉSTÖRTÉNETE MAGYARORSZÁGON
}

\section{HISTORICAL DEVELOPMENT OF HUNGARIAN BANKRUPTCY PREDICTION}

A folyóiratcikk a vállalatok fennmaradásával kapcsolatos elméleti megközelítések, valamint a csődelőrejelzés módszertanának és empirikus vizsgálatának fejlődéstörténetét igyekszik történelmi távlatban szintetizálni, a hangsúlyt az immár harminc éves múltra visszatekintő hazai empirikus csőd-előrejelzési modellek fejlődésére helyezve. A hazai csődelőrejelzés fejlődéstörténete alapján kijelenthető, hogy az napjainkra elérte a nemzetközi szakirodalom és gyakorlat színvonalát, a vizsgált kutatási kérdések, az alkalmazott módszerek és az empirikus eredmények tekintetében egyaránt.

A hazai csődelőrejelzés fejlődéstörténetében nyomon követhető az a fejlődési út, amely a kezdeti, keresztmetszeti adatokból és kisebb mintákon felépülő, klasszikus módszertanokkal történő csődelőrejelzéssel kezdődött, és napjainkra eljutott a dinamikus, through-the-cycle szemléletű tőkemodellek követelményeinek megfelelő vállalati minősítő rendszerek kialakításáig, amelynek módszertani továbbfejlesztését jelenleg a mesterséges intelligencia, az adatbányászat, a gépi tanulás és a hibrid modellezés dominálja.

A tanulmány rámutat arra, hogy a hazai vállalatok csődelőrejelzésére a hazai csődmodellek alkalmazása célravezető. A modellfejlesztés során különös tekintettel kell lenni a mintavételi problémákra, a célváltozó definícióra, a megfelelő adatelőkészítési és adattranszformációs műveletek elvégzésére, a változók dinamizálására, valamint a viselkedési változók figyelembevételére. A tanulmány számos normatív javaslatot fogalmaz meg az egyes csőd-előrejelzési módszerek kiválasztására vonatkozóan.

Kulcsszavak: csődelőrejelzés, klasszifikációs módszertan, hitelkockázat-kezelés, vállalati rating rendszerek

The article attempts to synthesize the historical development tendencies of theoretical approaches, methodologies and empirical researches of corporate survival and bankruptcy prediction, laying emphasis on the 30-year development history of Hungarian empirical bankruptcy prediction models. Based on the historical development of Hungarian bankruptcy prediction it can be argued that it has already caught up to the level of international best practice regarding the examined research problems, applied methods and empirical results.

Throughout the development history of Hungarian bankruptcy prediction it can be tracked, how the initial, small, crosssectional sample and classical methodology based bankruptcy prediction has evolved to today's corporate rating systems meeting the requirements of the dynamic, through-the-cycle economic capital calculation models. Contemporary methodological development is characterized by the domination of artificial intelligence, data mining, machine learning and hybrid modelling.

The article reveals that Hungarian bankruptcy models are necessary to accomplish efficient bankruptcy prediction in Hungary. Throughout model development, it is essential to consider the sampling problems, the definition of target variable, the proper accomplishment of data preparation and data transformation steps, the dynamization of variables and the inclusion of behavioural variables. In addition the article draws several normative proposals how to select the right bankruptcy prediction method(s).

Keywords: bankruptcy prediction, classification methodology, credit risk management, corporate rating systems

\section{Finanszírozás/Funding:}

A szerzők a tanulmány elkészítésével összefüggésben nem részesültek pályázati vagy intézményi támogatásban. The authors did not receive any grant or institutional support in relation with the preparation of the study.

\section{Szerzők/Authors:}

Dr. Kristóf Tamás, egyetemi docens, Budapesti Corvinus Egyetem, (tamas.kristof@uni-corvinus.hu) Dr. Virág Miklós, egyetemi tanár, Budapesti Corvinus Egyetem, (miklos.virag@uni-corvinus.hu) 
A vállalatok fennmaradásának és megszünésének kérdésköre hosszú ideje foglalkoztatja a társadalomtudósokat. A szervezet- és vezetéstudományi kutatások egyik alapkérdése, hogy miért maradnak fenn bizonyos szervezetek, miközben mások csődbe mennek. A szakirodalomban évtizedek óta számottevő publikáció született a business failure, a corporate survival, a bankruptcy prediction, az organizational mortality, a financial distress és a credit scoring szakterületeken, amelyek a szakavatott olvasók számára különböző dolgoknak tünhetnek, ugyanakkor közös bennük, hogy vállalatok különböző leíró jellemzőinek segítségével igyekeznek valamely kudarcra utaló esemény bekövetkezését előrejelezni, nagy átfedéssel hasonló módszertanok alkalmazásával.

A folyóiratcikk a vállalatok fennmaradásával kapcsolatos elméleti megközelítések, valamint a csődelőrejelzés módszertanának és empirikus vizsgálatának fejlődéstörténetét igyekszik történelmi távlatban szintetizálni, a hangsúlyt az immár harminc éves múltra visszatekintő hazai empirikus csőd-előrejelzési modellek fejlődésére helyezve. A tanulmány csőd-előrejelzési módszertan fejlődését a lineáris többváltozós statisztikai eljárásoktól napjaink legkorszerübb, mesterséges intelligencián alapuló gépi tanulási eljárásokig dolgozza fel, valamennyi módszertan hazai alkalmazására empirikus eredményeket biztosítva.

Megállapítható, hogy a csődelörejelzés szakterülete elsősorban a vállalatok fennmaradásának, illetve csődbe jutásának empirikus vizsgálatát támogatja, a csődbe jutás okainak feltérképezése, valamint a többváltozós klasszifikációs és elörejelzési módszertan folyamatos fejlesztése révén. Ez a témakör az elmúlt ötven évben jelentős fejlödésen ment keresztül, amelyet a Vezetéstudomány olvasói is számos publikáción keresztül folyamatosan nyomon követhettek.

\section{Elméleti fejlődéstörténet a szervezet- és vezetéstudomány tükrében}

A gazdasági rendszerben a gazdasági szervezetek folyamatos be- és kilépése természetes jelenség. Schumpeter (1934) szerint a vállalati csőd a hatékony piacgazdaság szükségszerü velejárója, amely lehetővé teszi a humán, fizikai és pénzügyi erőforrások átforgatását más, produktívabb vállalatokba.

A vállalatok megszünésére a szervezetelmélet több oldaláról is születtek magyarázatok (Mellahi \& Wilkinson, 2004). A klasszikus industrial organization és a szervezeti ökológia a környezet determinisztikus szerepét hangsúlyozza, és azt állítja, hogy a menedzserek számára a külső iparági és környezeti feltételek kevés teret engednek a döntésekhez, ezáltal nem ők tehetnek a csődről. Ezzel szemben a magatartástudományi, politikai, döntéselméleti és szervezetpszichológiai megközelítések voluntarisztikus megközelítéssel élnek, és azt állítják, hogy a menedzserek tevékenységei, döntései és megérzései okozzák a csődöt. Az igazság nyilvánvalóan mindkettőben megtalálható.

A szervezetek fennmaradásával kapcsolatos kutatásokban két tendencia különíthető el (Anheier \& Moulton, 1999). A szakterületet vizsgáló tanulmányok nagyobb része makroszinten készül. A pénzügyi fizetőképesség modellezésén kívül a tanulmányok általában a szervezeti populáció dinamikáját, valamint a populációba való belépést és kilépést vizsgálják. Leginkább kiterjedt fennmaradás-vizsgálatot a populációs ökológiai irányzat képviselői végeztek. A kutatások kisebb hányada esettanulmány jellegü szervezetspecifikus elemzésekben ölt testet, különös tekintettel a szervezetek hatékonyságra és más teljesítménykritériumokra. A menedzsment oldaláról a teljesség igénye nélkül különböző magatartási jellemzők, a helytelenül kialakított szervezeti struktúra, az információs aszimmetria, a megalapozatlan döntések, az önhittségi effektus, de az előrelátás hiánya is, egyaránt szerepet játszhatnak a csődbe jutásban (Jáki, 2013a, 2013b). A menedzsment-szakirodalomban a szervezetek fennmaradása gyakran került különböző nagyvállalatok „tündöklése és bukása” tartalmú könyvekben publikálásra (Kristóf, 2008b).

A kvantitatív elemzések és esettanulmányok alapján számos elmélet született a szervezetek fennmaradására (Virág et al., 2013). A jobbára empirikus vizsgálatokból született általánosítások azonban nem forrtak össze a szervezetek fennmaradását magyarázó egységes elméletté, azok sokkal inkább egymással versengő és egymást kiegészítő irányzatok maradtak. Ilyen feltételek mellett olyan elméletek számítanak ,jónak”, amelyek minél több aspektusból világítanak rá a szervezetek fennmaradására, vagyis, amelyek egyszerre képesek foglalkozni a szervezeti fennmaradás kontingenciaelméleti, tranzakciós költségelméleti, ügynökelméleti, politikai, életciklus, kognitív, strukturális, erőforrás-alapú, evolúciós és döntéselméleti oldalaival, amellett, hogy azok nem törekednek magas szintü absztrakcióra. A releváns szervezetelméleti iskolák elemzésével részletesen foglalkozott Kristóf (2005b). Tekintettel arra, hogy a szervezetelméleti iskolák és az empirikus vizsgálatok megállapításai több ízben egymásnak ellentmondó következtetésekre jutottak, a szervezetek fennmaradásának vizsgálatához egységes, általánosan elfogadásra javasolt elméleti-metodológiai szempontrendszert nem lehetséges definiálni.

Érdekes elméleti problémákat vethet fel, hogy a kidolgozott matematikai-statisztikai csőd-előrejelzési modellek mennyiben képesek hozzájárulni a szervezetek fennmaradásával és csődbe jutásával foglalkozó elméleti megfontolásokhoz. Blaug (1980) szerint a közgazdaságtan számos területén megfigyelhető, hogy a különböző ökonometriai tanulmányok egymásnak ellentmondó következtetésekre jutnak, és a rendelkezésre álló adatokból kiindulva nem létezik valamely legjobbnak kiválasztott módszer, ami alapján el lehetne dönteni, hogy melyik következtetés áll közelebb a valósághoz. Ebből következően akár évtizedekig is lehet vizsgálni egymásnak ellentmondó hipotéziseket (Westgaard, 2005).

Annak ellenére, hogy a modellfejlesztési erőfeszítések eredményeképpen számos értékes összefüggést sikerült feltárni, a csődelőrejelzés több évtizedes története alatt nem született általános érvényű megegyezés arról, hogy milyen magyarázó változók alapján lehetséges leginkább megbízhatóbban előrejelezni a fizetésképtelenséget. A rendkívül széles körű előrejelzési módszerek, a különböző országokból, iparágakból és időszakokból összegyűjtött adatok megnehezítik annak hipotetizálását, hogy mi okoz- 
za a csődöt és hogyan. A magyarázó változókra vonatkozó elméleti háttér hiánya súlyos akadályozó tényező a csődelőrejelzés átfogó elméletének kidolgozásában. Általánosan elfogadott elmélet nélkül pedig a tudományban eröltetett dolog kimondani, hogy valamely empirikus vizsgálat eredményeképpen született modell más időszakban és más gazdasági környezetben is müködöképes. Következésképpen kijelenthető, hogy nem létezik tértől, időtől és gazdasági környezettől független csődmodell.

A csődelőrejelzés tudományos elörejelezhetőségi problémája nem egyedüli jelenség a társadalomtudományok területén, amely hosszú ideje szolgál tudományos viták alapjául (Kristóf, 2006). Az 1950-es évek végéig a predikcióalkotás képessége alapján ítélték meg a tudományelméleteket. Széles körben csak az 1970-es évekre kerekedett felül az elméletek heurisztikai ereje a predikciókészítés képességén. Az univerzális predikcióra képes csődmodell lehetőségét elméletileg is el kell vetni, mivel a gazdaságban és a társadalomban nincsenek a természeti törvényekhez hasonló univerzalitások, amelyekre hosszú távú általánosításokat lehetne építeni, leszámítva bizonyos triviális szabályszerüségeket. Amenynyiben ugyanis lehetséges lenne a csődhöz hasonló társadalmi-gazdasági események pontos tudományos elörejelzése, akkor elvileg lehetőség nyílna az eljövendő gazdasági tények egyfajta lajstromozására. Ha azonban ez a lajstrom ismertté válna, akkor az sokakat minden bizonnyal olyan cselekedetekre ösztönözne, amelyek éppen az előrejelzett esemény bekövetkezését akadályoznák meg.

Elméleti oldalról tehát meglehetősen nehézkes egyértelmü magyarázatot adni a szervezetek fennmaradására/csődbe jutására. A megoldás a több lábon álló elméletalkotás, a több elméleti megközelítés együttes figyelembevétele, valamint a több elörejelzési módszer szimultán alkalmazása lehet. Az empirikus modellépítésben nagyobb szerepet szükséges engedni az elméletnek, ezáltal a statisztikai feltételek vizsgálatát mindig elméleti kontextusban kell elvégezni. A tudományterület fejlődése érdekében a hipotézisvizsgálatok eredményeit vissza kell csatolni az elméletalkotásba.

A tanulmány céljaival összhangban a csődelőrejelzést megalapozó szervezetelméleti megközelítéseknél általánosságban említett szervezeteket a továbbiakban a gazdasági szervezetekre (vállalatokra) szükítjük. Az elméleti magyarázatokon túllépve joggal vetődhet fel a kérdés, hogy milyen módszerek alkalmazása célravezető a hatékony csődelőrejelzés érdekében.

\section{Módszertani fejlődéstörténet a csődelőrejelzés nemzetközi szakirodalmában}

A vállalatok csődelőrejelzése évtizedek óta számottevő érdeklődésre számot tartó kutatási területnek számít. Du Jardin (2010) kutatása alapján a csődelőrejelzés fejlödéstörténete során világszerte mintegy 500 változó felhasználásával és 50 különböző módszerrel publikáltak csődmodelleket. Jelen tanulmány a legelterjedtebb, a tudományterületre és a gyakorlati alkalmazásra legnagyobb hatást gyakorló módszereket dolgozza fel.

Módszertani szempontból a csődelőrejelzés egy bináris klasszifikációs probléma, amelynek lényege, hogy minél pontosabban különbséget tudjunk tenni a fizetőképes és a fizetésképtelen vállalatok két csoportja között (Virág, 2004). A csődelőrejelzés a vállalati pénzügyek, illetve a statisztika (adatbányászat) határtudományának tekinthető, amely a pénzügyi mutatószámokat magyarázó változóként felhasználva tesz kísérletet a vállalatok jövőbeli fizetőképességének elörejelzésére, valamely arra alkalmas többváltozós módszer alkalmazásával (Nyitrai, 2015a).

A XX. század első felében nem álltak rendelkezésre fejlett statisztikai módszerek és számítógépek a csődelőrejelzést végzők számára. A fennmaradt és a csődbe jutott vállalatok pénzügyi mutatószámait hasonlították össze, és megállapították, hogy a leggyakrabban alkalmazott mutatószámok a csődbe jutott vállalatok esetében kedvezőtlenebbek voltak (Fitzpatrick, 1932). Az első módszertani áttörés akkor következett be, amikor Durand (1941) egyváltozós diszkriminanciaanalízison alapuló credit scoring modellt publikált. A módszer világszerte később Beaver (1966) egyváltozós diszkriminanciaanalízis modelljével terjedt el.

Felismerve, hogy a megfigyelések egyetlen változó alapján történő csoportosítása nem ad megbízható eredményt, Myers \& Forgy (1963) többváltozós regreszszióelemzést és többváltozós diszkriminanciaanalízist alkalmazott banki ügyfelek hitelkockázati minősítési rendszerének kidolgozásához. A magasabb kockázatú ügyfeleknél a többváltozós diszkriminanciaanalízis megbízhatóbb eredményt tudott felmutatni, különösen a korábban alkalmazott szakértői scoringhoz viszonyítva, ami miatt a módszerre egyre többen felfigyeltek. Az átütő sikert Altman (1968) világhírü többváltozós diszkriminanciaanalízis modellje hozta, amely 95 százalékos pontossággal volt képes felismerni az eredeti mintában szereplő fizetésképtelen és problémamentes vállalatokat. A modell az azóta eltelt évtizedekben több felülvizsgálaton ment keresztül. A számos sikeres alkalmazása ellenére azonban napjainkra világossá váltak a korlátjai, amelyek egyrészt a diszkriminanciaanalízis szigorú alkalmazási feltételeire, másrészt a hard default célváltozó alkalmazására vezethetők vissza, valamint a modell gyakorlati hasznosságát csökkentette az a tény, hogy az meglehetősen szűk vállalati körön (amerikai tőzsdei vállalatok) került kifejlesztésre, ezáltal is korlátot jelentve a mintavételben szereplő vállalkozásokétól eltérő populáción történő alkalmazása felé.

Az 1970-es évektöl a tudományterület fejlődését a klasszifikációs feladatok megoldására alkalmas matematikai-statisztikai eljárások, valamint az azt támogató informatikai háttér korszerüsödése dominálta (Nyitrai, 2015a). A diszkriminanciaanalízis eloszlási és szóródási feltételein túllépve, a hasonló alkalmazási feltételeket nem támasztó logisztikus regressziós elemzést (logit) elöször Chesser (1974) alkalmazta csődelőrejelzésre, hitelkockázatkezelési adatbázison. A logit globális szintű elterjedésében mérföldkőnek bizonyult Ohlson (1980) tanulmánya, aki 105 fizetésképtelen és 2058 fizetőképes vállalat mintán fejlesztett logit modellt, ezzel is kifejezve, hogy a fizetésképtelen vállalatok a sokaságban kisebb arányt képviselnek, mint a fizetőképesek. Hasonló módszertani okokból kezdődött meg az 1980-as évektől a probit regresszió csőd-előrejelzési alkalmazása, amely Zmijewski (1984) nevéhez köthető. 
Az 1980-as évektől kezdtek elterjedni a nemparaméteres módszerek, amelyek nem támasztottak statisztikai alkalmazási feltételeket. A klasszifikációs problémák megoldásában és az adatbányászatban a mai napig rendkívül népszerü döntési fákat elöször Frydman, Altman \& Kao (1985) alkalmazta csődelőrejelzésre.

Az 1990-es években számos kritika érte a lineáris vagy linearizálható, robusztus modelleket, és a korábban alkalmazott módszereket, amelynek hatására a mesterséges intelligencia módszercsaládba tartozó neurális hálók új lendületet adtak a csődelőrejelzés megbízhatóságának javításához (Kristóf, 2005a). A neurális hálókat először Odom \& Sharda (1990) alkalmazta csődelörejelzésre, amelynek során igazolást nyert, hogy a háromrétegü neurális háló modell felülmúlta a korábbi módszertanokkal kifejlesztett csődmodellek teljesítményét. A neurális hálók azóta rendkívül széles körben elterjedtek, számottevő továbbfejlődésen mentek keresztül, és napjainkban is rendkívül népszerü módszert képviselnek.

A neurális hálók terjedésével egyidejűleg a csődmodellezésben egyre szélesebb teret nyertek a korszerü vizuális klaszterezési eljárások. A felülvizsgálatlanul tanuló neurális hálók elvén müködő önszerveződő térképek (SOM) segítségével lehetővé vált ismeretlen kimenettel rendelkező adatbázis klaszterezése, látványos vizualizációs technikákkal (Kiviluoto, 1998). A többdimenziós skálázás az adatok közötti rejtett összefüggéseket vizualizálja, többdimenziós koordinátákba tömörítve azokat (Neophytou \& Mar Molinero, 2004).

A 2000-es évek elejétől intenzíven kutatott területté vált a neuro-fuzzy rendszerek csőd-előrejelzési alkalmazása, amelyekkel sikerült a hagyományos neurális hálóknál jobb modellteljesítményt elérni (Vlachos \& Tolias, 2003). Ezzel párhuzamosan kezdett meghonosulni a Support Vector Machine (SVM) eljárás, amelynek alkalmazásával először ausztrál vállalatok mintáján, húszszoros keresztvalidációval igazolták az SVM magasabb klasszifikációs teljesítményét a neurális hálókhoz és más korábbi eljárásokhoz viszonyítva (Fan \& Palaniswami, 2000). A 2000-es években terjedt el továbbá a Rough Set Theory (Dimitras et al., 1999), a $k$ legközelebbi szomszéd (Ardakhani et al., 2016), a Bayes-i háló (Sun \& Shenoy, 2007), a genetikus algoritmusok (Lensber, Eilifsen \& McKee, 2006), a Learning Vector Quantization (Neves \& Vieira, 2006), valamint a Case-Based Reasoning (Bryant, 1997) csőd-előrejelzési alkalmazása.

A 2010-es évekre a klasszifikációs módszerek önálló alkalmazása helyett egyre inkább elterjedt a módszerkombinációk speciális esetének tekinthető metamódszerek alkalmazása (Marqués, Garciá \& Sánchez, 2012). Ezek lényege, hogy a modellfejlesztési adatbázisból többször véletlen visszatevéses mintát vesznek, és ezeken alkalmaznak valamely klasszifikációs eljárást. A végső modell klasszifikációs ereje az egyes modellek által adott elörejelzések átlagolásával adódik, amely általában meghaladja a metamódszerek alkalmazása nélkül adódó klasszifikációs erőt. Leggyakoribb metamódszerek a gépi tanulási eljáráscsaládba tartozó boosting, bagging, random suspace, random forest, Gauss-folyamatok és az Autoencoder (Nyitrai, 2015a; Wang, 2017). Napjaink csőd-előrejelzési kutatásait egyértelműen a gépi tanulás, az adatbányászat és a mesterséges intelligencia, valamint az új eljárások egymással történő kreatív kombinációjával a hibrid modellépítés dominálja (Barboza, Kimura \& Altman, 2017). A csődelörejelzés mint többváltozós klasszifikációs probléma rendkívül népszerü gyakorlati alkalmazási területet képvisel az egyre korszerübb és megbízhatóbb algoritmusok megtalálását célul kitűző adatbányászati versenyeken, amelyeken az egyre innovatívabb megoldások egyre szélesedő tárháza válik napról napra publikussá.

\section{A hazai empirikus csődelőrejelzés fejlődéstörténete}

Magyarországi viszonyok között a csődelörejelzés tudományos vizsgálatának lehetősége az 1990-es évek elejére teremtődött meg, a jogi értelemben vett csődbe jutást szabályozó első csődtörvény megjelenésével. Az elmúlt harminc évben a csődelőrejelzés magyar vonatkozású szakirodalma és gyakorlata jelentős fejlődésen ment keresztül. Tekintettel a változatos kutatási célokra és adatbázisokra, a kidolgozott csődmodellek klasszifikációs erőiben empirikusan mért különbségeket az alkalmazott magyarázó és a célváltozó definíció és kör függvényében kell értelmezni. A szakterület fontosságát jól jelzi, hogy a csődelőrejelzés elméleti kérdésköreivel, módszertani kihívásaival és/vagy gyakorlati alkalmazásaival kapcsolatban Magyarországon eddig tizennégy doktori értekezés született (Virág, 1993; Arutyunjan, 2002; Kiss, 2003; Imre, 2008; Kristóf, 2008b; Oravecz, 2009; Kotormán, 2009; Felföldi-Szücs, 2011; Hámori, 2014; Madar, 2014; Nyitrai, 2015a; Bozsik, 2016; Fejér-Király, 2016; Koroseczné, 2016). Különösen erős volt a 2016. év, amikor három értekezés készült.

Az első hazai vállalati csőd-előrejelzési tanulmányt Futó Péter készítette el az Ipargazdasági Intézetben 1989ben, hazai iparvállalatok 1986-1987. évi beszámoló adatainak és 1988-ban megfigyelt fizetésképtelenségi esemény bekövetkezésének felhasználásával, szóráselemzés és egyszerüsített diszkriminanciaanalízis alkalmazásával. A fizetésképtelenségi esemény az volt, hogy 1988. első 6 hónapja közül a vállalatok legalább 2 hónapban nem tudták fizetni a tartozásukat. A tanulmány nem került publikálásra, annak eredményeit később Virág és Hajdu (1998) ismertette. Az empirikus eredmények rámutattak arra, hogy hazai viszonyok között is megvizsgálható, hogy melyek azok a pénzügyi mutatók, amelyek leginkább alkalmasak a közelgő csőd előrejelzésére.

A hazánkban először publikált csődmodelleket Virág Miklós dolgozta ki, 10 hónapos amerikai tanulmányutat követően, 1990. és 1991. éves beszámoló adatok alapján, diszkriminanciaanalízis és logit segítségével (Virág, 1993). A modellépítés során a szerző 15 pénzügyi mutatószámot vett figyelembe. A vizsgálatba bevont 154 feldolgozóipari vállalatból 1992-ben 77 fizetőképes és 77 fizetésképtelen volt. A fizetésképtelen vállalatok az 1991-ben elfogadott csődtörvény hatályba lépését követően azonnal csődeljárást kellett, hogy kérjenek maguk ellen. A négyváltozós diszkriminanciaanalízis modell 78 százalékos, az ötváltozós logit modell 82 százalékos besorolási pontosságot mutatott (Virág, 1996). 
A Virág \& Hajdu (1996) szerzőpáros elkészített egy korai csődveszélyt jelző modellcsaládot különböző nemzetgazdasági ágakra és ágazatokra vonatkozóan, diszkriminanciaanalízis segítségével, közel 10000 gazdálkodó egység pénzügyi adatai alapján. Összesen 41 csődmodell készült el: egy a gazdaság egészére, 10 a nemzetgazdasági ágakra és 30 az ágazatokra. A nemzetgazdasági ágakat és ágazatokat átfogó csődmodell-család pontossága a tevékenységi kör szerinti részletezés miatt felülmúlta a korábbi modellekét, valamennyi modell 90 százalék feletti besorolási pontosságú volt. A szerzők hazánkban először vonták le azt a következtetést, hogy a minősítés során első körben azt célszerü vizsgálni, hogy egy adott cég pénzügyi arculata milyen mértékü hasonlóságot mutat azokhoz a cégekhez, amelyek az adott tevékenyégi körben (ágban, ágazatban) hazánkban csődbe jutottak, illetve ebből a szempontból problémamentesnek minősülnek (Hajdu \& Virág, 2001).

Hámori (2001) úgy transzformálta a felhasznált pénzügyi mutatókat logit modelljéhez, hogy azok megítélése monoton legyen. A szerző a mutatók értékkészletét is határok közé szorította, az outlier adatokat elöre definiált elméleti maximumra cserélte le. A multikollinearitás kiküszöbölésére a mutatókból négy faktort hozott létre. A mintában 685 fizetőképes és 72 fizetésképtelen vállalat szerepelt. A négy faktorra épített modell besorolási pontossága 95 százalék volt.

A hazai mezőgazdaságban tevékenykedő vállalkozásokra vizsgálta Arutyunjan (2002) számos külföldi diszkriminanciaanalízis alapú modelljeinek alkalmazhatóságát. Összességében a szerző nem tartotta megfelelőnek a külföldi modelleket hazai mezőgazdasági cégekre alkalmazni, ezért helyettük saját logit modellt fejlesztett ki, amelylyel 92 százalékos besorolási pontosságot ért el.

Kiss (2003) a credit scoring modellezés oldaláról közelítette meg a kérdéskört, együttes fejlődéstörténeti keretrendszert kialakítva a csődelőrejelzés és a credit scoring területére. Értekezésének eredménye a statisztikai módszerek hierarchiába rendezése, valamint a scoring rendszerekhez kapcsolódó szervezeti, informatikai és döntéstámogatói szempontrendszer kidolgozása.

Virág \& Dóbé (2005) a hazai viszonyokra korábban felállított csődmodell család segítségével nemzetgazdasági ágazatok fizetőképességét vizsgálta. Az input változókat az ágazati szinten aggregált kimutatásokból készítették el, 30 nemzetgazdasági ágazatot és 15 pénzügyi mutatót figyelembe véve. A szerzők a nemzetgazdasági ágazatok átlagos mutatószámainak együttesét tekintették elemzési egységnek (centroidnak). Megállapítást nyert, hogy az ágazatok többségének átlagos képe jobban hasonlít saját túlélő vállalataihoz, mint a csődösökéhez.

Az első hazai csődmodell adatbázisán Virág \& Kristóf (2005a) épített neurálisháló-alapú csődmodelleket. Többféle hálóstruktúrával kísérletezve a végül legjobbnak bizonyult, két köztes réteget tartalmazó, négyrétegü backpropagation háló teljesítménye a diszkriminanciaanalízisét mintegy 9, a logit modellét 5 százalékponttal haladta meg Virág \& Kristóf (2005b). Ugyanez a szerzőpáros szintén az első hazai csődmodell adatbázisát használta egy még kiterjedtebb komparatív empirikus vizsgálat lefolytatására, amelyben négy klasszifikációs módszer előrejelző képességét vetették össze iparági relatív mutatók alkalmazása mellett. Eredményeik ebben az esetben is azt mutatták, hogy a neurális hálók hatékonyabban képesek a csőd előrejelzésére, mint a hagyományos módszerek (Virág \& Kristóf, 2006).

A Bázel II magyarországi bevezetésének közeledtével a Pénzügyi Szervezetek Állami Felügyelete (PSZÁF) 2006ban pályázatot írt ki a pénzintézetek kockázatkezelését elősegítő módszerek és azok alkalmazását támogató adatbázisok kidolgozására. A győztes tanulmány (Info-Datax, 2006) elöször módszertani oldalról igyekezett feltárni a nemfizetési valószínűség becslés eszközeként használható statisztikai módszerek problémáit, majd főkomponenselemzéssel történő adattömörítés után empirikus vizsgálattal hasonlította össze a diszkriminanciaanalízis, a logit és a döntési fa teljesítményét, 1500 vállalatból álló mintán. Mindhárom módszerrel 87-88 százalék közötti besorolási pontosságot értek el.

A csődelőrejelzés módszertanával kapcsolatos fejlödéstörténeti összefoglalót adott Halas (2004), Szabadosné \& Dávid (2005), Oravecz (2007), Szücs (2014), Ratting (2015), illetve Reizinger-Ducsai (2016), saját empirikus modellfejlesztésre azonban nem vállalkoztak. Különböző korábban publikált csődmodellek alkalmazhatóságát vizsgálta kismintán mezőgazdasági vállalkozásokra Kotormán (2009), élelmiszeripari vállalkozásokra Rózsa (2014), húsipari feldolgozó vállalkozásokra Petö \& Rózsa (2015), kereskedelmi vállalkozásokra Dorgai, Fenyves \& Sütö (2016), valamint szálláshely-szolgáltató vállalkozásokra Fenyves et al. (2016), több-kevesebb sikerrel. Kismintákon végzett a szakterületen különböző empirikus modellfejlesztést Sütő (2008) és Ékes \& Koloszár (2014).

A vállalatok fennmaradását magyarázó szervezetelméleti megközelítéseket, a csődelőrejelzés elméleti, metodológiai és gyakorlati problémáit, valamint a legjobb gyakorlatot tükröző csőd-előrejelzési módszereket hozta közös nevezőre Kristóf (2008b). A szakágazati átlagokkal korrigált pénzügyi mutatókon főkomponens-elemzéssel és anélkül fejlesztett csődmodellek közül a tesztelő mintán legjobbnak a két neurális háló modell bizonyult 8484 százalékos Receiver Operating Characteristic (ROC) görbe alatti terület (AUROC) értékkel, amelyet a fökomponenseken lefuttatott logit modell követett (83 százalék), majd az eredeti változókon épített döntési fa (81 százalék). Hazánkban első alkalommal került továbbá alkalmazásra csődmodellezési célra a többdimenziós skálázás és az önszerveződő térképek módszere, amelyek klaszterező és változószelekciós képessége igazolást nyert.

A bázeli through-the-cycle szemléletü modellezés követelményeinek megfelelően Magyarországon először Imre (2008) alkalmazott idősoros input változókat 2000 hazai vállalat 2002-2006. közötti tényadatainak felhasználásával, a változók körét a cégformával, megyével és ágazattal kiegészítve. A döntési fával, logit regresszióval és neurális hálóval épített modellek célváltozója a 90 napos fizetési késedelem bekövetkezése volt. A változók dinamizálását mellőzve, statikus szemléletben a tesztelő 
mintán az AUROC 90 százalék volt a logit és a neurális háló modellek esetén, ugyanakkor csupán 83 százalék a döntési fa esetén. A mutatók éves változását kifejező dinamikus változók közbeiktatásával a neurális háló teljesítménye 92 százalékra, a logité 91 százalékra, a döntési fáé 84 százalékra javult, ezáltal hazánkban első alkalommal igazolást nyert a dinamikus változók klasszifikációs erőnövelö képessége.

A modellépítési minta reprezentativitásával és a szelekciós torzítás kérdéskörével foglalkozott részletesen Oravecz (2009). Az értekezés eredménye az adathiány típusokból levezetett adathiány kezelési technikák, valamint a credit scoring modelleknél fellépő szelekciós torzítás csökkentésére kidolgozott reject inference módszerek. 2279 elemű adatbázison logit regressziós modellezéssel igazolást nyert, hogy az erősebb szelekció gyengébb modellteljesítményhez vezet.

A csődelörejelzés időközben Erdélyben is igyekezett felzárkózni a nemzetközi legjobb gyakorlathoz. Az első erdélyi magyar csődmodelleket Benyovszki \& Kibédi (2008) dolgozta ki 129 nagybányai vállalat mintáján logit és probit regresszióval, mindkét modellel közel 81 százalékos besorolási pontosságot elérve. A leginkább kiterjedt fejlődéstörténeti, módszertani és empirikus vizsgálatot a 2010-es években Székelyföldön folytatták le, amelynek keretében logit regresszióval és neurális hálókkal készültek különböző csődmodellek Hargita megyei vállalkozások mintáján (Fejér-Király, 2015; Fejér-Király, 2016; Fejér-Király, 2017). Megállapítható, hogy a Hargita megyei vállalkozások csődviselkedése eltér a Magyarországon tapasztaltaktól, hiszen a vállalati méret nem bizonyult szignifikáns változónak, ellenben a forgási sebesség mutatókkal. Igazolást nyert továbbá, hogy főkomponenselemzéssel és makrováltozók bevonásával jobb modellek adódnak, mint anélkül.

Kismintás elemzés keretében Virág \& Kristóf (2009) a fizetőképes és fizetésképtelen megfigyeléseket egy alacsonyabb dimenziószámú térbe képezték le koordinátákként a többdimenziós skálázás segítségével, majd a redukált dimenziószámú térben alkalmazták a logisztikus regresszió módszerét kiemelkedő találati aránnyal.

A felszámolások előrejelzésével foglalkozott 10-250 M Ft közötti árbevételü nyugat-dunántúli korlátolt felelősségű vállalkozások mintáján neurális hálók alkalmazásával Bareith, Koroseczné \& Kövér (2014). A válság miatt a rendelkezésre álló adatbázist két gazdasági ciklusra bontották: 2002-2008. és 2009-2012. közötti időszaki beszámoló adatokra. Mindkét periódusban három év pénzügyi mutatóit vették figyelembe a modellépítés során, relatív fontosság alapú változószelekcióval kiszürve a nem releváns változókat, egy-egy köztes réteget alkalmazva. A két időszakra kidolgozott modellben több dinamikus mutató is szerepelt. A 2002-2008. közötti időszaki modell 85, a 2009-2012. közötti időszaki modell 79 százalékos besorolási pontosságot ért el. A három szerző két évvel később hasonló módszertan alkalmazásával, de nem kettébontva az adatgyüjtési időszakot, a modellezést elvégezte Csongrád megyei vállalkozásokra is, amelynek során még jobb klasszifikációs erejü neurális háló modellt fejlesztettek ki (Bareith, Koroseczné \& Kövér, 2016). Felszámolási eljárás alá került kisvállalko- zások pénzügyi mutatóinak viselkedését vizsgálta továbbá Koroseczné (2016) a felszámolást megelőző években, számos hasznos empirikus eredményt felmutatva.

A szállítók által a vevőknek nyújtott kereskedelmi hitelekhez kapcsolódó vevői nemfizetés elörejelezhetőségét vizsgálta Felföldi-Szücs (2015) 905 hazai kis- és középvállalkozás mintáján. A modellezési célváltozó a vevők 90 napos fizetési késedelme volt. A szerző a banki hitelkockázati modellek analógiájára logit regresszióval igazolta, hogy a viselkedési, nem pénzügyi változók (Felföldi-Szücs, 2011) magasabb diszkrimináló erővel rendelkeznek, mint a hagyományos pénzügyi adatokra épülő változók.

A bázeli követelményrendszernek megfelelően Madar (2014) olyan vállalati rating rendszert dolgozott ki logit regresszióval, amely hosszú távú nemteljesítési valószínüség becslésre és gazdasági tőkeszámításra is alkalmasnak bizonyult, egy 2007-2012. időszaki adatokból összeállított, több tízezer elemszámból álló hitelintézeti mintaportfólió felhasználásával. A tanulmány az eredeti változókat Weightof-Evidence (WOE) transzformációval helyettesítette. A célváltozó a cenzorált default ráta volt. A szerző rámutatott a modellstabilitás és a nemteljesítési valószínűség kalibráció fontosságára és javasolt technikáira, amelynek a válságidőszakban megfigyelhető jelentősen magasabb nemteljesítési valószínüségek adnak különösen értelmet.

Az egyes csőd-előrejelzési módszereket összehasonlító elemzések mellett egyre szélesebb körben jelentek meg az adatelőkészítési és adattranszformációs müveletek fontosságát hangsúlyozó publikációk (Kristóf, 2008a). Az adatelőkészítési müveletek (hiányzó értékek, outlierek, nullával osztások, kettős negatív osztások, nulla per nulla osztások stb.) felismerésének és megfelelő kezelésmódjainak fontosságára hívta fel a figyelmet számos módszertani lehetőséggel és gyakorlati példával alátámasztva, kézikönyvként is alkalmazható publikációjában Hámori (2014).

A stock és flow szemléletű mérleg- és eredménytételek megfelelő viszonyításának hatásait vizsgálta a csődmodellek teljesítményére Nyitrai (2017). Az outlierek különböző kezelésmódjának modellteljesítményre gyakorolt hatásáról Nyitrai \& Virág (2018) empirikusan azt a következtetést vonta le, hogy a Chi-square automatic interaction detection (CHAID) döntési fákkal történő kategorizálás jobban kezeli az outliereket, mint a különböző percentilisek, illetve az átlag \pm különböző mértékű szórások mentén történő csonkolás.

Tovább vizsgálva a döntési fák modellteljesítményre gyakorolt jótékony hatását, 504 hazai vállalat mintáján igazolást nyert, hogy a CHAID döntési fákkal diszkretizált változók felhasználásával a logit regresszióval és neurális hálóval felépített modellek teljesítménye tovább javítható, az eredeti változókból épített modellekével öszszehasonlítva (Kristóf \& Virág, 2012). Ugyanezen adatbázison azonban a főkomponens-elemzés nem hozott érdemben változást az egyes modellek előrejelző erejében.

A döntési fák és a neurális hálók kombinálásának hatékonyságára mutatott rá Bozsik (2011). A szerző a C4.5 döntési fa csúcsaihoz egyrétegü perceptron hálókat rendelt 250 vállalat mintájára, 17 változó felhasználásával. A kifejlesztett brute force és a finomított vékony modellel egyaránt 84 százalékos besorolási pontosságot ért el. 
Az SVM módszert hazai vállalati adatokon elöször Virág \& Nyitrai (2013) alkalmazta az első hazai csődmodell adatbázisán. Különböző kernel függvények alkalmazásával összességében az SVM modell 5 százalékponttal magasabb találati arányra volt képes az első hazai csődmodell adatbázisán, mint a korábbi empirikus vizsgálatok során legjobbnak bizonyult neurális háló modell.

A gépi tanulásra épülési eljárások hazai meghonosításának keretében a halmazelméleten alapuló Rough Set Theory (RST) módszer alkalmazását próbálta ki szintén az első hazai csődmodell adatait felhasználva Virág \& Nyitrai (2014a). Egyúttal a szerzők arra kérdésre is választ kerestek, hogy érdemes-e lemondani a modellek értelmezhetőségéröl a magasabb klasszifikációs teljesítmény érdekében. Az eredmény azt mutatta, hogy a könnyen értelmezhető „ha-akkor” típusú szabályokat generáló RST módszert alkalmazva az SVM algoritmussal azonos találati arány érhető el, ezért nem szükségszerü az átváltás a modellek interpretálhatósága és teljesítménye között.

Virág \& Nyitrai (2014b) a két leggyakrabban alkalmazott metamódszer (AdaBoost, bagging) teljesítményét hasonlította össze a C4.5 döntési fák alkalmazása esetén, 976 hazai vállalkozás 2001-2012. közötti megfigyelt időszakra kiterjedő mintáján. A nyers pénzügyi mutatókra épített modellek találati arányát összevették a modellváltozók szakágazati átlagokkal történő korrekcióját és a dinamizálását követően is. A mintavételi problémák elkerülésére százszoros keresztvalidációt alkalmaztak. Legjobb eredményt a bagging eljárással érték el, amelytől mintegy 1 százalékponttal maradt el az AdaBoost, és 6 százalékponttal a C4.5 önálló alkalmazása. Az empirikus eredmények újfent igazolták a dinamikus változók modellteljesítmény növelő hatását, a szakágazati korrekció utáni változókkal azonban nem javult az eredmény.

A k legközelebbi szomszéd eljárást Magyarországon elöször Nyitrai (2015b) alkalmazta hazai vállalkozások csődelőrejelzésére. A tanulmány 1000 elemü, kiegyensúlyozott mintán azt vizsgálta, különböző $k$ értékekkel és távolságfogalmakkal, hogy a csődesemény bekövetkezése előtti 1, 2, illetve 3 évvel képzett pénzügyi mutatókból, valamint a több időszakot egyszerre alkalmazó változókból milyen besorolási pontossággal képes a módszer előrejelezni a csődöt. Legjobb eredményt a több időszakot tartalmazó modell érte el (80 százalék), amelyet a csődöt közvetlenül megelőző 1 év adataira épített modell követett (77 százalék). Az eredmények arra is rámutattak, hogy bizonyos mutatószámok inkább rövid távon, míg mások hosszabb távon adnak korai figyelmeztető jelzéseket a hazai vállalkozások potenciális csődveszélyére vonatkozóan. A szerző az empirikus vizsgálatot ugyanabban az évben elvégezte CHAID döntési fákkal is, és hasonló következtetésre jutott (Nyitrai, 2015a).

A k legközelebbi szomszéddal rokon CBR módszert alkalmazta csődelőrejelzésre Kristóf (2018a) 1828 hazai mikrovállalkozás mintáján. Az inputváltozók egymásra ortogonálissá tételére a tanulmány fökomponens-elemzést alkalmazott, a legközelebbi szomszédok a Reduced Dimensionality Tree (RDT) módszerrel kerültek megállapításra. A CBR modell teljesítménye ugyan a döntési fáét meghaladta és a logit regresszióéhoz hasonló volt, de elmaradt a benchmark modellként alkalmazott neurális hálóétól.

A dinamikus modellezés területén kiemelendő Bauer \& Endrész (2016) tanulmánya, amelyben nagyon hosszú, 1996-2014. közötti időszakra kiterjedő, mikro- és makrováltozók kombinálásával építettek probit csődmodellt a teljes hazai kettős könyvelést végző vállalkozások populációjára, jogi szempontú csődbe jutást célváltozóként vizsgálva, figyelembe véve a vállalati méret szerinti heterogenitást. A kifejlesztett modell teljesítménye 86 százalékos AUROC volt.

Jegybanki és hitelintézeti kutatási céllal épített a teljes hazai hitelezett kis- és középvállalati szektorra nemteljesítési valószínűség modelleket Banai et el. (2016) a Központi Hitelinformációs Rendszer (KHR) és a vállalkozások pénzügyi beszámoló adatainak összekapcsolásával, makrogazdasági változókkal kiegészítve. Az adatgyüjtés 2007-2014. közötti időszakra terjedt ki, a modellezési célváltozó a hátralékos hiteltörlesztésből képzett nemteljesítési esemény bekövetkezése volt. A logit regresszióval felépített dinamikus szemléletű modelleket a vállalkozások méretei alapján szegmentálták, bizonyos változókat kategorizáltak, késleltettek, diszkretizáltak. A mikrovállalkozások 75 százalékos, a kisvállalkozások 79 százalékos, a közepes vállalkozások 84 százalékos AUROC teljesítményt értek el. Ez a modellteljesítmény alacsonyabb volt, mint a jogi értelemben vett csődöt kifejező célváltozóval készült modellek, de ennek oka, hogy a KHR mulasztási esemény (60 napos fizetési hátralék) lényegesen enyhébb feltételnek számít, mint a tényleges csődbe jutás.

Hasonló vizsgálatot végzett 2001-2014. közötti időszakra összegyüjtött 1542 hazai vállalkozás pénzügyi mutatóinak idősorain Nyitrai \& Virág (2017b), tízszeres keresztvalidációval készített logit regresszióval. A modellezési adatbázison minden egyes historikus időszakra viszszatekintően elvégezték a változók dinamizálását a Nyitrai (2014) által korábban publikált eljárással. Az AUROC értéke tendenciózusan erösebb modellteljesítményt jelzett, minél több historikus évet vettek figyelembe a modellépítés során, amelynek alapján megállapítást nyert, hogy tíz évnél fiatalabb vállalkozások esetében a teljes idősor tükrében, ennél idősebb cégeknél pedig az utolsó évtized tükrében érdemes megítélni a modellek előrejelző képességét. Ugyanez a szerzőpáros egy másik, 1354 vállalkozást tartalmazó mintán is elvégezte ezt a vizsgálatot, amelynek eredményei megerősítették a fenti megállapításokat (Nyitrai \& Virág, 2017a), összhangban egy korábbi 1082 vállalkozás mintáján a három leggyakoribb döntési fával elvégzett modellezés eredményeképpen (Virág \& Nyitrai, 2015).

A csődmodellek dinamizálásának előrejelző eröre gyakorolt pozitív hatását Nyitrai (2019) igazolta a legfrissebb hazai empirikus vizsgálattal. A pénzügyi mutatók időbeli trendjét indikátorváltozók fejezték ki, az előző időszakok minimum és maximum értékeit benchmarkként szerepeltetve a modellekben. A tízszeres keresztvalidációval felépített diszkriminanciaanalízis, logit és döntési fa modellek egyaránt azt mutatták, hogy a dinamizált változók javítják a klasszifikációs teljesítményt a hagyományos statikus mutatókból felépített modellekkel összehasonlítva. 
A vállalati méret és tevékenységi kör csődmodellekre gyakorolt hatását vizsgálta Nyitrai (2018), 2614 hazai vállalkozás 2007-2015. közötti beszámoló adatain. Logit modellekkel igazolást nyert, hogy a vállalatok tevékenységi köre és mérete egyaránt befolyásolja a modellek felépítését és teljesítményét.

A megfelelő adatelőkészítési lépések elvégzését követően 1534 hazai kisvállalkozás kiegyensúlyozott mintáján alkalmazta Boda et al. (2016) különböző lépcsőfüggvényekkel a Component-Based Object Comparison for Objectivity (COCO) hasonlóságelemzést, különböző rétegekkel és szabályrendszerekkel a WizWhy adatbányászati eljárást, valamint benchmarkként a logit regressziót és a neurális hálót csődelőrejelzésre. A COCO, a logit és a neurális háló modell egyaránt 80 százalékos besorolási pontossággal rendelkezett, a többféle logikával optimalizált, a részeredményekre több körben építő hibrid szabályrendszeren alapuló WizWhy módszerrel ugyanakkor 92 százalékos találati arányt értek el.

Felismerve a rugalmas és jó adaptív képességekkel rendelkező mesterséges intelligencia modellezés lehetőségeit, azok kombinálásával az egyik módszerek előnyeit a másik módszerek előnyeivel ötvözve a modellteljesítmény javító potenciáljukat, több hibrid mesterséges intelligencia alapú csődmodellt dolgozott ki Bozsik (2016). A számos modellkísérletet és új ötletet felvonultató tanulmányból kiemelkedőnek tartjuk a fuzzy rendszerrel kombinált SVM (FSVM) modellt, amely a Gauss típusú kernel függvény alkalmazásával 93 százalékos besorolási pontosságot mutatott. Szintén ígéretes a Gauss tagsági függvénnyel felépített, ötrétegű adaptív neuro-fuzzy modell (ANFIS), amely 84 százalékos besorolási pontossággal rendelkezett.

A gépi tanulási algoritmusok hitelkockázati modellteljesítményre gyakorolt hatásvizsgálatával kísérletezett számos eljárással Boros (2018) 10000 vállalkozás adataiból összetevődő modellezési adatbázison. A változószelekción, főkomponens-elemzésen és WOE kategorizáláson átesett adatbázison végül a neurális háló jobbnak bizonyult (82 százalékos AUROC), mint az SVM (81 százalékos AUROC) és a sztochasztikus gradient boosting (76 százalékos AUROC). A kategorizálás nélküli eredeti változókon fejlesztett kiinduló modellek lényegesen rosszabb teljesítményt mutattak.

A pénzügyi instrumentumokra 2018-tól hatályba lépett nemzetközi számviteli standardoknak (IFRS-9) történő megfelelés szükségessé tette a korábban a csődesemény egy évre előretekintő bekövetkezését kifejező célváltozó hosszú távra történő kiterjesztését. A pénzügyi instrumentumok lejáratáig, húsz éves előretekintéssel készített folytonos, inhomogén Markov láncokkal csődvalószínüség előrejelző modelleket hazai nagyvállalatokra Kristóf \& Virág (2017), illetve Kristóf (2018b).

\section{Következtetések}

A tanulmány a vállalatok fennmaradásával kapcsolatos elméleti megközelítések, valamint a csődelőrejelzés módszertanának és empirikus vizsgálatának fejlődéstörténetét igyekezett történelmi távlatban szintetizálni, a hangsúlyt az immár harminc éves múltra visszatekintő hazai empirikus csőd-előrejelzési modellek fejlődésére helyezve. A hazai csődelőrejel- zés fejlődéstörténete alapján kijelenthető, hogy az napjainkra elérte a nemzetközi szakirodalom és gyakorlat színvonalát, a vizsgált kutatási kérdések, az alkalmazott módszerek és az empirikus eredmények tekintetében egyaránt.

A hazai csődelörejelzés fejlődéstörténetében nyomon követhettük azt a fejlödési utat, amely az egyszerübb, keresztmetszeti adatokból felépülö, kisebb mintákon, klasszikus módszertanokkal történő csődelőrejelzéssel kezdödött, és napjainkra eljutott a dinamikus, throughthe-cycle szemléletü tökemodellek követelményeinek megfelelő vállalati minősítő rendszerek kialakításáig, amelynek módszertani továbbfejlesztését jelenleg a mesterséges intelligencia, az adatbányászat, a gépi tanulás és a hibrid modellezés dominálja.

A releváns nemzetközi szakirodalom ismeretében, valamint a hazai csődelőrejelzés teljes körüen kielemzett empirikus eredményei alapján a következő normatív javaslatokat fogalmazzuk meg a jövőben csődelőrejelzéssel foglalkozni kívánó kutatók és gyakorlati szakemberek számára:

- Különös tekintettel arra az elméleti megállapításra is, hogy nem létezik tértől, időtől és gazdasági környezettől független csődmodell, nem javasoljuk külföldi vállalati mintákra kifejlesztett csődmodelleket hazai vállalatokra alkalmazni, akármilyen népszerüséggel és idézettséggel is rendelkeznek a külföldi tanulmányok. Amennyiben saját modellfejlesztésre nincs lehetőség, jelen tanulmány rámutatott arra, hogy a hazai vállalkozások reprezentatív adatbázisaira, rendkívül változatos módszerekkel, számottevő magyar csődmodell került publikálásra, amelyek hazai vállalatok minősítésére és csődvalószínűség becslésére igazoltan jól alkalmazhatók.

- Az adatelőkészítési és adattranszformációs műveletek megfelelő elvégzésének jelentős szerepe van a modellek előrejelző erejének alakulásában, amelyek korrekt megvalósítása szinte annál is fontosabb, mint hogy melyik klasszifikációs módszert alkalmazzuk csődelörejelzésre. Az adattranszformációs műveletek közül kiemeljük az inputváltozók kategorizálását, amely egyszerre javítja a csődmodellek előrejelző képességét, kezeli az outliereket és időben stabilabbá teszi a modelleket. Erre a célra igazoltan alkalmas a döntési fákkal és a WOE-val elvégzett kategorizálás.

- A historikus adatbázisokból felépülő csődmodellek alapján megállapítható, hogy az inputváltozók dinamizálása javítja a csődmodellek előrejelző képességét. Minél hosszabb idősorra tekintünk vissza a változók dinamizálása során, annál jobb eredményt kaphatunk. Ez a megállapítás a modellstabilitás javítására hatványozottan érvényes. Ezzel egyidejüleg figyelni kell arra, hogy ezek a modellek csupán a szükséges számú lezárt üzleti évvel rendelkező vállalkozásokra alkalmazhatók, következésképpen a fiatalabb cégekre másik, kevésbé jó klasszifikációs erejü modell kifejlesztése is szükségessé válik.

- Amennyiben a nyilvánosan rendelkezésre álló információforrásokból számítható pénzügyi mutatókon túlmenően megfelelő ismeretekkel és adatokkal rendelkezünk az adott vállalati ügyfelek/partnerek pénz- 
ügyi viselkedéséről, az ezekből előállított viselkedési változók modellfejlesztésbe történő bekapcsolásával jobb modellteljesítmény adódik, mint pusztán a normál pénzügyi mutatók figyelembevétele alapján.

- A csőd-előrejelzési adatbázis összeállítása során figyelmet kell fordítani a szelekciós torzítás problémájára, ami igazoltan rontja a modellteljesítményt. A kisebb mintákon fejlesztett csődmodellek mintavételi problémáit ugyanakkor igazoltan kezeli a keresztvalidáció, amely megfelelő kezelésmódot biztosít a túltanulás elkerülésére is. A csődmodellek teljesítményére ezzel egyidejüleg jelentős hatást gyakorol a célváltozó definíciója, hiszen a fizetési hátralékból képzett nem teljesítési esemény lényegesen enyhébb feltételnek számít, mint a jogi értelemben vett tényleges csődbe jutás. Amennyiben megfelelően nagy minta áll rendelkezésre, a vállalati méret és az ágazat mentén szegmentált modellfejlesztés igazoltan célszerü.

- A modellfejlesztési módszertant illetően a jelenlegi gyakorlatban leginkább elterjedt a logisztikus regreszszión és a neurális hálókon alapuló csődmodellezés, amelyet harmadikként a döntési fák alkalmazása követ. Tekintettel arra, hogy ugrásszerüen növekszik a mesterséges intelligencia és adatbányászati módszertanok alkalmazása, ezért javasoljuk, hogy minimum benchmark modellként a három leggyakrabban alkalmazott módszertannal kifejlesztett modellel kerüljön összehasonlításra bármilyen új modell klasszifikációs ereje. Kifejezetten bátorítjuk a hibrid modellek kifejlesztését, hiszen azok sikeresen ötvözik az egyik módszerek előnyeit a másik módszerek előnyeivel, ami szintén modellteljesítmény javító hatással jár. Szükséges ezzel egyidejüleg elismerni, hogy a szigorú matematikai-statisztikai alkalmazási feltételeket támasztó, klasszikus csőd-előrejelzési módszerek (diszkriminanciaanalízis) alkalmazása jól láthatóan modellteljesítmény problémákat vethet fel, amely lényeges ellenérv a hosszú idők alatt megszokott könnyü interpretálhatósággal szemben.

\section{Felhasznált irodalom}

Altman, E. I. (1968). Financial ratios, discriminant analysis and the prediction of corporate bankruptcy. The Journal of Finance, 23(4), 589-609. DOI: https://doi. org/ 0.1111/j.1540-6261.1968.tb00843.x.

Anheier, H. K. \& Moulton, L. (1999). Organizational Failures, Breakdowns, and Bankruptcies. In Anheier, H. K. (Ed.), When Things Go Wrong. Organizational Failures and Breakdowns (pp. 3-14). Thousand Oaks: Sage Publications.

Ardakhani, M., Mehrjerdi, V. Z., Sarvi, M., \& Sarvi, E. (2016). A survey of the capability of $k$ nearest neighbors in prediction of bankruptcy of companies based on selected industries. Scinzer Journal of Accounting and Management, 2(4), 27-37. DOI: https://doi. org/10.21634/SJAM.2.4.2737.

Arutyunjan Alex (2002). A mezőgazdasági vállalatok fizetésképtelenségének elörejelzése. (PhD-értekezés). Gödöllő: Szent István Egyetem.
Banai Ádám, Körmendi Gyöngyi, Lang Péter, \& Vágó Nikolett (2016). A magyar kis- és középvállalati szektor hitelkockázatának modellezése. MNB tanulmányok 123. Budapest: Magyar Nemzeti Bank.

Barboza, F., Kimura, H., \& Altman, E. I. (2017). Machine learning models and bankruptcy prediction. Expert $S y$ stems with Applications, 83(10), 405-417. DOI: https:// doi.org/10.1016/j.eswa.2017.04.006.

Bareith Tibor, Koroseczné Pavlin Rita, \& Kövér György (2014). Felszámolások vizsgálata a Nyugat-dunántúli régióban. E-CONOM, 3(2), 102-124. DOI: https://doi. org/10.17836/EC.2014.2.102.

Bareith Tibor, Koroseczné Pavlin Rita, \& Kövér György (2016). Felszámolások előrejelzésének vizsgálata Csongrád megyei vállalkozások esetén. In Kovács Attila \& Bíró Gyöngyvér (Szerk.), Móra Akadémia Szakkollégiumi Tanulmánykötet (pp. 11-26). Szeged: Szegedi Tudományegyetem Móra Ferenc Szakkollégium.

Bauer, P. \& Endrész, M. (2016). Modelling bankruptcy using Hungarian firm-level data. MNB Occasionnal Papers 122. Budapest: Magyar Nemzeti Bank.

Beaver, W. (1966). Financial ratios as predictors of failure. Empirical research in accounting: selected studies. Journal of Accounting Research, 4(3), 1-111. DOI: https://doi.org/10.2307/2490171.

Benyovszki Annamária \& Kibédi Kamilla Klára (2008). Vállalati csődelörejelzés többváltozós statisztikai módszerrel. Közgazdász Fórum, 11(7), 3-17.

Blaug, M. (1980). The Methodology of Economics: or How Economists Explain. Los Angeles: Boland.

Boda, D., Luptak, M., Pitlik, L., Szücs, G., \& Takács, I. (2016). Prediction of insolvency of Hungarian micro enterprises. In Proceedings of the ENTRENOVA - ENTerprise Research InNOVAtion Conference (pp. 352-359). Rovinj, Croatia, 8-9 September 2016. Zagreb: IRENET - Society for Advancing Innovation and Research in Economy.

Boros Bence (2018). Artificial intelligence and automation in credit scoring. Budapest: KPMG Tanácsadó Kft.

Bozsik, J. (2011). Decision tree combined with neural networks for financial forecast. Periodica Polytechnica Electrical Engineering, 55(3-4), 95-101. DOI: https://doi.org/10.3311/pp.ee.2011-3-4.01.

Bozsik József (2016). Heurisztikus eljárások alkalmazása a csődelörejelzésben (PhD-értekezés). Budapest: Eötvös Loránd Tudományegyetem.

Bryant, S. M. (1997). A case-based reasoning approach to bankruptcy prediction modeling. Intelligent $S y$ stems in Accounting, Finance and Management, 6(3), 195-214. DOI: https://doi.org/10.1002/(SICI)10991174(199709)6:3<195::AID-ISAF132>3.0.CO;2-F.

Chesser, D. (1974). Predicting loan noncompliance. Journal of Commercial Bank Lending, 56(8), 28-38.

Dimitras, A.I., Slowinski, R., Susmaga, R., \& Zopounidis, C. (1999). Business failure prediction using rough sets. European Journal of Operational Research, 114(2), 263-280. DOI: https://doi.org./10.1016/S0377-2217(98)00255-0.

Dorgai, K., Fenyves, V., \& Sütő, D. (2016). Analysis of Commercial Enterprises' Solvency By Means of Different Bankruptcy Models. Gradus, 3(1), 341-349. 
Du Jardin, P. (2010). Predicting bankruptcy using neural networks and other classification methods: The influence of variable selection techniques on model accuracy. Neurocomputing, 70(10-12), 2047-2060. DOI: https://doi.org/10.1016/j.neucom.2009.11.034.

Durand, D. (1941). Risk elements in consumer instalment financing. New York: National Bureau of Economic Research.

Ékes, K. Sz. \& Koloszár, L. (2014). The efficiency of bankrutpcy forecast models in the Hungarian SME sector. Journal of Competitiveness, 6(2), 56-73. DOI: https:// doi.org/10.7441/joc.2014.02.05.

Fan, A. \& Palaniswami, N. (2000). Selecting bankruptcy predictors using a support vector machine approach. In Proceedings of the International Joint Conference on Neural Networks (pp. 354-359). Neural Computing: New Challenges and Perspectives for the New Millennium. DOI: https://doi.org/10.1109/ IJCNN.2000.859421.

Fejér-Király, G. (2015). Bankruptcy prediction: A survey on evolution, critiques, and solutions. Acta Universitatis Sapiantiae Economics and Business, 3(1), 93-108. DOI: https://doi.org/10.1515/auseb-2015-0006.

Fejér-Király Gergely (2016). Csödelörejelzö modellek alkalmazhatósága Hargita megyei vállalkozásoknál (PhD-értekezés). Gödöllő: Szent István Egyetem.

Fejér-Király Gergely (2017). Csődelőrejelzés a KKV-szektorban pénzügyi mutatók segítségével. Közgazdász Fórum, 20(130), 3-29.

Felföldi-Szűcs Nóra (2011). Hitelezés vevői nemfizetés mellett: A bank és a szállitó hitelezési döntése (PhDértekezés). Budapest: Budapesti Corvinus Egyetem.

Felföldi-Szücs Nóra (2015). A vevői nemfizetés előrejelzése viselkedési jellemzők segítségével. Gradus, 2(2), 1-9.

Fenyves, V., Dajnoki, K., Domicián, M. \& Baji-Gál, K. (2016). Examination of the solvency of enterprises dealing with accommodation service providing in the Northern Great Plain Region. SEA: Practical Application of Science, 4(2), 197-203.

Fitzpatrick, P. (1932). A comparison of the ratios of successful industrial enterprises with those of failed companies. Washington: The Accountants' Publishing Company.

Frydman, H., Altman, E. I., \& Kao, D. L. (1985). Introducing recursive partitioning for financial classification: The case of financial distress. The Journal of Finance, 40(1), 269-291. DOI: https://doi. org/10.1111/j.1540-6261.1985.tb04949.x.

Hajdu, O. \& Virág, M. (2001). A Hungarian model for predicting financial bankruptcy. Society and Economy in Central and Eastern Europe, 23(1-2), 28-46.

Halas Gábor (2004). Hogyan mérjünk nemfizetési valószinüséget? Módszertani összehasonlitás. Mérés-HatárMühely tanulmány. Budapest: Info-Datax Kft.

Hámori Gábor (2001). A fizetésképtelenség előrejelzése logit-modellel. Bankszemle, 45(1-2), 65-87.

Hámori Gábor (2014). Predikciós célú klasszifikáló statisztikai modellek gyakorlati kérdései (PhD-értekezés). Kaposvár: Kaposvári Egyetem.
Imre Balázs (2008). Bázel II definíciókon alapuló nemfizetés-elörejelzési modellek magyarországi vállalati mintán (2002-2006) (PhD-értekezés). Miskolc: Miskolci Egyetem.

Info-Datax (2006). Módszertani elemzés a nemfizetési valószínüség modellezéshez. A PSZÁF „A pénzügyi szervezetek kockázatainak (partner, múködési, likviditási stb.) tőkemegfelelési követelményeiből adódó, üzleti alkalmazásokat segítő módszerek kidolgozása és a módszerek müködéséhez szükséges adatbázisok kiépítése" c. pályázatára készült tanulmány. Budapest: Info-Datax Kft.

Jáki Erika (2013a). A válság, mint negatív információ és bizonytalansági tényező - A válság hatása az egy részvényre jutó nyereség elörejelzésekre. Közgazdasági Szemle, 60(12), 1357-1369.

Jáki Erika (2013b). Szisztematikus optimizmus a válság idején. Vezetéstudomány, 44(10), 37-49.

Kiss Ferenc (2003). A credit scoring fejlödése és alkalmazása (PhD-értekezés). Budapest: Budapesti Müszaki Egyetem.

Kiviluoto, K. (1998). Predicting bankruptcies with the selforganizing map. Neurocomputing, 21(1-3), 191-201. DOI: https://doi.org/10.1016/S0925-2312(98)00038-1.

Koroseczné Pavlin Rita (2016). A felszámolási eljárás alá került hazai kisvállalkozások helyzetének elemzése (PhD-értekezés). Kaposvár: Kaposvári Egyetem.

Kotormán Annamária (2009). A mezögazdasági vállalkozások felszámolásához vezető okok elemzése (PhD-értekezés). Debrecen: Debreceni Egyetem.

Kristóf Tamás (2005a). A csődelőrejelzés sokváltozós statisztikai módszerei és empirikus vizsgálata. Statisztikai Szemle, 83(9), 841-863.

Kristóf Tamás (2005b). Szervezetek jövőbeni fennmaradása különböző megközelítésekben. Vezetéstudomány, 36(9), 15-23.

Kristóf, T. (2006). Is it possible to make scientific forecasts in social sciences? Futures, 38(5), 561-574. DOI: https://doi.org/10.1016/j.futures.2005.09.004.

Kristóf Tamás (2008a). A csődelőrejelzés és a nem fizetési valószínüség számításának módszertani kérdéseiről. Közgazdasági Szemle, 55(5), 441-461.

Kristóf Tamás (2008b). Gazdasági szervezetek fennmaradásának és fizetöképességének elörejelzése (PhD-értekezés). Budapest: Budapesti Corvinus Egyetem.

Kristóf Tamás (2018a). A case-based reasoning alkalmazása a hazai mikrovállalkozások csődelőrejelzésére. Statisztikai Szemle, 96(11-12), 1109-1128. DOI: https:// doi.org/10.20311/stat2018.11-12.hu1109.

Kristóf Tamás (2018b). Vállalatok hosszú távú (15-20 éves) bedőlési valószínüségének elörejelzése. In Nováky Erzsébet \& S. Gubik Andrea (Szerk.), A múltból átívelö jövő: VIII. Magyar (Jubileumi) Jövőkutatási Konferencia: 50 éves a magyar jövőkutatás (pp. 193205). Budapest, 2018. november 14-15. Győr: Palatia Nyomda és Kiadó Kft.

Kristóf, T. \& Virág, M. (2012). Data reduction and univariate splitting - Do they together provide better corporate bankruptcy prediction? Acta Oeconomica, 62(2), 205-227. DOI: https://doi.org/10.1556/AOecon.62.2012.2.4. 
Kristóf, T. \& Virág, M. (2017). Lifetime probability of default modelling for Hungarian corporate debt instruments. In Zoltayné Paprika Zita et al. (Eds.), ECMS 2017: 31st European Conference on Modelling and Simulation (pp. 41-46). Nottingham: ECMS-European Council for Modelling and Simulation.

Lensberg, T., Eilifsen, A., \& McKee, T. E. (2006). Bankruptcy theory development and classification via genetic programming. European Journal of Operational Research, 169(2), 677-697. DOI: https://doi. org/10.1016/j.ejor.2004.06.013.

Madar László (2014). Scoring rendszerek hatásai a gazdasági tőkeszámitás során alkalmazott portfoliómodellek eredményeire (PhD-értekezés). Kaposvár: Kaposvári Egyetem.

Marqués, A. I., García, V., \& Sánchez, J. S. (2012). Exploring the behaviour of base classifiers in credit scoring ensembles. Expert Systems with Applications, 39(11), 1024410250. DOI: https://doi.org/10.1016/j.eswa.2012.02.092.

Mellahi, K. \& Wilkinson, A. (2004). Organizational failure: a critique of recent research and a proposed integrative framework. International Journal of Management Reviews, 5-6(1), 21-41. DOI: https://doi.org/10.1111/ j.1460-8545.2004.00095.x.

Myers, J. H. \& Forgy, W. (1963). The development of numerical credit evaluation systems. Journal of the American Statistical Association, 58(303), 799-806. DOI: https://doi.org/10.1080/01621459.1963.10500889.

Neophytou, E. \& Mar Molinero, C. (2004). Predicting Corporate Failure in the UK: A Multidimensional Scaling Approach. Journal of Business Finance and Accounting, 31(5-6), 677-710. DOI: https://doi. org/10.1111/j.0306-686X.2004.00553.x.

Neves, J. C. \& Vieira, A. (2016). Improving bankruptcy prediction with hidden layer Learning Vector Quantization. European Accounting Review, 15(2), 253-271. DOI: https://doi.org/10.1080/09638180600555016.

Nyitrai Tamás (2014). Növelhető-e a csőd-előrejelző modellek előrejelző képessége az új klasszifikációs módszerek nélkül? Közgazdasági Szemle, 66(5), 566-585.

Nyitrai Tamás (2015a). Dinamikus pénzügyi mutatószámok alkalmazása a csödelörejelzésben (PhD-értekezés). Budapest: Budapesti Corvinus Egyetem.

Nyitrai Tamás (2015b). Hazai vállalkozások csődjének előrejelzése a csődeseményt megelőző egy, két, illetve három évvel korábbi pénzügyi beszámolók adatai alapján. Vezetéstudomány, 46(5), 55-65.

Nyitrai Tamás (2017). Stock és flow típusú számviteli adatok alkalmazása a csődelőrejelző modellekben. Vezetéstudomány, 48(8-9), 68-77. DOI: https://doi. org/10.14267/VEZTUD.2017.09.07.

Nyitrai Tamás (2018). A vállalatok tevékenységi körének és méretének hatása a csődelőrejelző modellekre. Statisztikai Szemle, 96(10), 973-1000. DOI: https://doi. org/10.20311/stat2018.10.hu0973.

Nyitrai, T. (2019). Dynamization of bankruptcy models via indicator variables. Benchmarking: An International Journal, 26(1), 317-332. DOI: https://doi.org/10.1108/ BIJ-03-2017-0052.
Nyitrai Tamás \& Virág Miklós (2017a). A pénzügyi mutatók időbeli tendenciájának figyelembevétele logisztikus regresszióra épülő csődelőrejelző modellekben. Statisztikai Szemle, 95(1), 5-28. DOI: https://doi. org/10.20311/stat2017.01.hu0005.

Nyitrai Tamás \& Virág Miklós (2017b). Magyar vállalkozások felszámolásának elörejelzése pénzügyi mutatóik idősorai alapján. Közgazdasági Szemle, 64(3), 305-324. DOI: https://doi.org/10.18414/KSZ.2017.3.305.

Nyitrai, T. \& Virág, M. (2018). The effects of handling outliers on the performance of bankruptcy prediction models. Socio-Economic Planning Sciences, 67(September), 3442. DOI: https://doi.org/10.1016/j.seps.2018.08.004.

Odom, M. D. \& Sharda, R. (1990). A neural network model for bankruptcy prediction. In Proceeding of the International Joint Conference on Neural Networks, San Diego, 17-21 June 1990, Vol. II. (pp. 163-171). Ann Arbor: IEEE Neural Networks Council.

Ohlson, J. A. (1980). Financial ratios and the probabilistic prediction of bankruptcy. Journal of Accounting Research, 18(1), 109-131. DOI: https://doi. org/10.2307/2490395.

Oravecz Beatrix (2007). Credit scoring modellek és teljesítményük értékelése. Hitelintézeti Szemle, 6(6), 607-627.

Oravecz Beatrix (2009). Szelekciós torzitás és csökkentése az adósminősitési modelleknél (PhD-értekezés). Budapest: Budapesti Corvinus Egyetem.

Pető, D. \& Rózsa, A. (2015). Financial future prospect investigation using bankruptcy forecasting models in Hungarian meat processing industry. Annals of the University of Oradea Economic Science, 24(1), 801-809.

Ratting Anita (2015). Fizetésképtelenség-elörejelzési megközelítések. Társadalom és Gazdaság, 7(3), 53-73.

Reizinger-Ducsai, A. (2016). Bankruptcy prediction and financial statements. The reliability of a financial statement for the purpose of modeling. Research papers of Wroclaw University of Economics Nr. 441. (pp. 202213). DOI: https://doi.org/10.15611/pn.2016.441.14.

Rózsa, A. (2014). Financial performance analysis and bankruptcy prediction in Hungarian dairy sector. Annals of Faculty of Economics, 1(1), 938-947. DOI: https://doi.org/10.1108/CR-12-2014-0041.

Schumpeter, J. (1934). The Theory of Economic Development. Cambridge: Harvard Business Press.

Sun, L. \& Shenoy, P. P. (2007). Using Bayesian networks for bankruptcy prediction: Some methodological issues. European Journal of Operational Research, 180(2), 738-753. DOI: https://doi.org/10.1016/j. ejor.2006.04.019.

Sütő Dávid (2018). Észak-alföldi élelmiszer-kiskereskedelmi vállalkozások pénzügyi helyzetének elemzése logitmodell segítségével. Acta Carolus Robertus, 8(1), 223-235. DOI: https://doi.org/10.24387/CI.2017.2.3.

Szabadosné Németh Zsuzsanna \& Dávid László (2005). A kis- és középvállalati szegmens mulasztási valószínűségének előrejelzése magyarországi környezetben. Hitelintézeti Szemle, 4(3), 39-58.

Szücs Tamás (2014). A csődmodellek és azok módozatai. E-Controlling, 14(9), 1-8. 
Virág Miklós (1993). Pénzügyi viszonyszámokon alapuló teljesitmény-megitélés és csődelörejelzés (Kandidátusi értékezés). Budapest: Budapesti Közgazdaságtudományi Egyetem.

Virág Miklós (1996). Pénzügyi elemzés, csődelörejelzés. Budapest: Kossuth Kiadó.

Virág Miklós (2004). A csődmodellek jellegzetességei és története. Vezetéstudomány, 35(10), 24-32.

Virág Miklós \& Dóbé Sándor (2005). A hazai csődmodell család alkalmazása ágazati centroidokra. Vezetéstudomány, 36(4), 45-54.

Virág Miklós \& Hajdu Ottó (1996). Pénzügyi mutatószámokon alapuló csődmodell-számítások. Bankszemle, 15(5), 42-53.

Virág Miklós \& Hajdu Ottó (1998). Pénzügyi viszonyszámok és csődelőrejelzés. In Bácskai Tamás et al. (Szerk.), Bankról, pénzröl, tőzsdéről. Válogatott elöadások a Bankárképzőben 1988-1998 (pp. 440-457). Budapest: Nemzetközi Bankárképző.

Virág Miklós \& Kristóf Tamás (2005a). Az első hazai csődmodell újraszámítása neurális hálók segítségével. Közgazdasági Szemle, 52(2), 144-162.

Virág, M. \& Kristóf, T. (2005b). Neural networks in bankruptcy prediction - a comparative study on the basis of the first Hungarian bankruptcy model. Acta Oeconomica, 55(4), 403-425. DOI: https://doi.org/10.1556/AOecon.55.2005.4.2.

Virág Miklós \& Kristóf Tamás (2006). Iparági rátákon alapuló csődelőrejelzés sokváltozós statisztikai módszerekkel. Vezetéstudomány, 37(1), 25-35.

Virág Miklós \& Kristóf Tamás (2009). Többdimenziós skálázás a csődmodellezésben. Vezetéstudomány, 40(1), 50-58.

Virág Miklós, Kristóf Tamás, Fiáth Attila, \& Varsányi Judit (2013). Pénzügyi elemzés, csődelörejelzés, válságkezelés. Budapest: Kossuth Kiadó.
Virág, M. \& Nyitrai, T. (2013). Application of support vector machines on the basis of the first Hungarian bankruptcy model. Society and Economy, 35(2), 227-248. DOI: https://doi.org/10.1556/SocEc.35.2013.2.6.

Virág M. \& Nyitrai T. (2014a). Is there a trade-off between the predictive power and the interpretability of bankruptcy models? The case of the first Hungarian bankruptcy prediction model. Acta Oeconomica, 64(4), 419-440. DOI: https://doi.org/10.1556/AOecon.64.2014.4.2.

Virág Miklós \& Nyitrai Tamás (2014b). Metamódszerek alkalmazása a csődelőrejelzésben. Hitelintézeti Szemle, 13(4), 180-195.

Virág Miklós \& Nyitrai Tamás (2015). Csődelőrejelző modellek dinamizálása. In Bakacsi Gyula, Balaton Károly, \& Dobák Miklós (Szerk.), Vezetés és szervezet társadalmi kontextusban: Tanulmányok Dobák Miklós 60. születésnapja tiszteletére (pp. 284-304). Budapest: Akadémiai Kiadó.

Vlachos, D. \& Tolias, Y. A. (2003). Neuro-fuzzy modeling in bankruptcy prediction. Yugoslav Journal of Operational Research, 13(2), 165-174. DOI: https://doi. org/10.2298/YJOR0302165V.

Wang, N. (2017). Bankruptcy Prediction Using Machine Learning. Journal of Mathematical Finance, 7(4), 908918. DOI: https://doi.org/10.4236/jmf.2017.74049.

Westgaard, S. (2005). What Can Modern Statistical and Mathematical Techniques Add to the Analysis and Prediction of Bankruptcy? Department of Industrial Economics and Technology Management, Trondheim: Norwegian University of Science and Techno$\log y$.

Zmijewski, M. E. (1984). Methodological issues related to the estimation of financial distress prediction models. Journal of Accounting Research, Supplement to Vol. 22, 59-82. DOI: https://doi.org/10.2307/2490859. 